\title{
Association between CAM 5.2 and anti-CD1a reactivity in lymph nodes and gastrointestinal tract epithelium
}

\author{
A S JACK, * I GRIGOR, * C J O'BRIEN, * W McMEEKIN, F LEWIS, * A M McNICOL \\ From the Departments of Pathology, *University of Leeds, and University of Glasgow
}

SUMMARY Immunocytochemical studies, using the antibodies CAM 5.2 and NA1/34 (CD1a), were performed on normal lymphoid tissue and malignant lymphomas. A population of dendritic cells in the paracortex of lymph nodes and in $\mathrm{T}$ cell lymphomas reacted with both antibodies. Colocalisation with antibodies was also found in gastrointestinal epithelium.

Immune blotting shows that the likely basis of this reactivity is a 12 kilodalton peptide which is recognised by both antibodies. This is almost certainly the $\beta$ t peptide which has been described as the light chain of CDla.

The immunocytochemical demonstration of the intermediate filament content of cells is an important aid in the diagnosis of tumours. The antibody CAM 5.2,' which recognises low molecular weight cytokeratins, is one of the most widely used reagents in routine histopathological practice. Recent reports of the reaction of this antibody with smooth muscle cells have raised the possibility that the epitope recognised by CAM 5.2 may be present on proteins which are not cytokeratins. ${ }^{23}$ CAM 5.2 reactivity has also been shown in some myeloma cells. ${ }^{4}$

A chance observation led to the present study. It was found that many reactive lymph nodes contained numerous CAM 5.2 positive cells which show none of the morphological features of epithelial cells. This finding prompted an attempt to identify the basis of this reaction.

\section{Material and methods}

\section{IMMUNOCYTOCHEMISTRY}

Ten specimens of reactive lymph node and 10 cases of $T$ cell malignant lymphoma were chosen for study. Samples of normal colonic and gastric epithelium were also obtained from unfixed surgical specimens.

Immunocytochemical staining for CAM 5.2 (Dako) was performed on frozen and paraffin wax sections; NA1/34 (anti-CD1a) (Dako) was used on frozen sections and coverslips with adherent HCT8 cells, a cell line derived from a colonic adenocarcinoma. CAM 5.2 was diluted to $1 / 20$ and used in a standard

Accepted for publication 6 October 1988 indirect immunoperoxidase technique. NA1/34 was used at 1/128 dilution in the same method. Several cases were also stained with the anticytokeratin antibody RPN1100, using a dilution of $1 / 8$.

\section{IMMUNE BLOTTING}

Human HCT8 line was grown in RPMI medium with $10 \%$ serum. Cells were removed using edetic acidTrypsin, pelleted and washed in phosphate buffered saline (PBS). Cells were lysed in $10 \mathrm{mM}$ Tris- $\mathrm{HCl}, 140$ $\mathrm{mM} \mathrm{NaCl}, 50 \mathrm{mM} \mathrm{MgCl}$ (TNM) buffer containing $1 \%$ Triton $X$ and spun at $3000 \mathrm{rpm}$ for 10 minutes. The supernatant was discarded and the pellet was resuspended in TNM buffer containing $0.5 \%$ Triton $X$ and $1.5 \mathrm{M} \mathrm{KCl}$. After incubation at $4^{\circ} \mathrm{C}$ for 30 minutes this was spun at $2000 \mathrm{rpm}$ for four minutes. Again the supernatant was discarded and the residue was dissolved in TNM buffer with $8 \mathrm{M}$ urea containing $0 \cdot 1 \mathrm{M}$ mercaptoethanol for two hours at room temperature. This was centrifuged for 60 minutes at $37000 \mathrm{rpm}$. The supernatant was dialysed overnight against distilled water to precipitate keratin filaments. A sample of this precipitate was removed for protein estimation and the remainder was spun at $37000 \mathrm{rpm}$ for 60 minutes. The pellet was suspended in sample buffer. This material was separated on a $10 \%$ polyacrylamide gel then blotted on to a nitrocellulose filter. These were stained with the antibodies CAM 5.2 and NA1/34 at the concentrations described above.

Immune blotting was also attempted using specimens of lymph node. The tissue was snap frozen in liquid nitrogen and suspended in $0.1 \mathrm{M}$ Tris, $10 \mathrm{mM}$ edetic acid at $\mathrm{pH} \mathrm{7.6.} \mathrm{The} \mathrm{subsequent} \mathrm{steps} \mathrm{were} \mathrm{as}$ described for the HCT8 cells. 
Results

\section{IMMUNOCY TOCHEMISTRY}

\section{Lymphoid tissue}

All non-neoplastic lymph nodes contained variable numbers of cells which reacted strongly with CAM 5.2 , and in the cases tested, RPN 1100. In most specimens a relatively small number of positive cells were present, the exception being cases of dermatopathic lymphadenopathy in which very large numbers of cells were found. These cells were dendritic in shape and were exclusively present in the paracortex, which, of course, is expanded in dermatopathic lymphadenopathy (fig 1). This pattern of staining was demonstrable in both paraffin wax and frozen sections. Similar cells were common in the cases of $T$ cell malignant lymphoma examined. These cells were never seen in diffuse $B$ cell lymphoma.

In adjacent sections, labelled with $\mathrm{NA1} / 34$, a similar

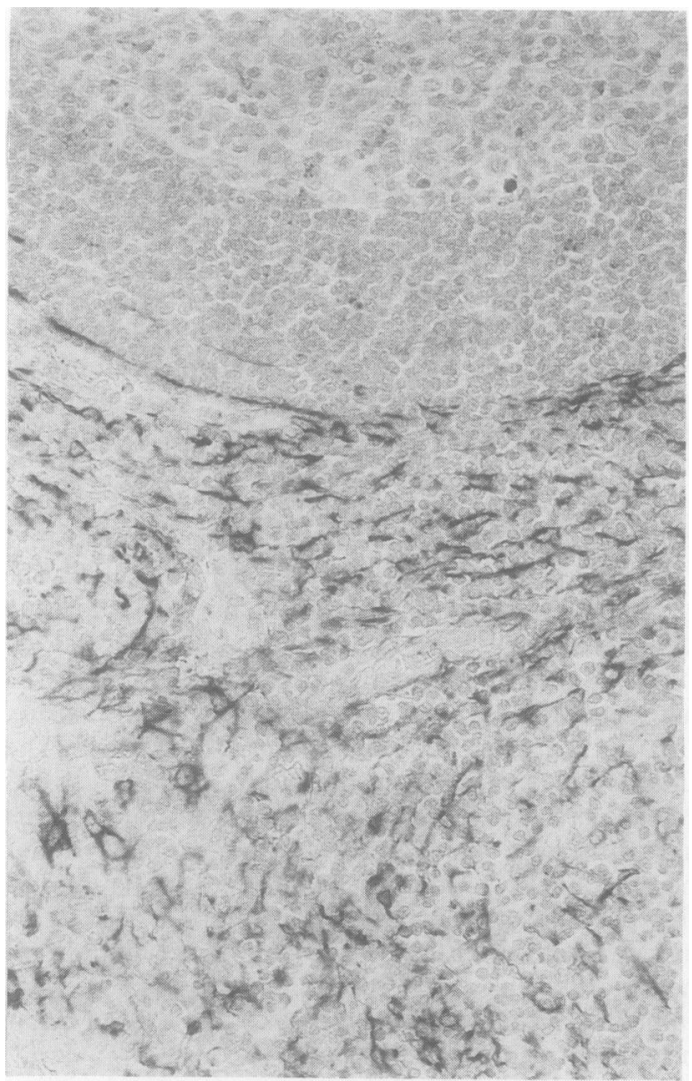

Fig 1 Paraffin wax section of lymph node showing feature of dermatopathic lymphoadenopathy. Many dendritic cells are shown by CAM 5.2 antibody. These are exclusively confined to the paracortex. population of cells was shown, although more cells seemed to react with this antibody than with CAM 5.2.

\section{Gastrointestinal tract epithelium}

Frozen sections of gastric and colonic epithelium and coverslips with adherent HCT8 (colonic adenocarcinoma) cells were used. CAM 5.2 reacted as expected with these specimens. NA1/34, however, also reacted with these tissues (fig 2) and cultured cells (fig 3), producing a predominantly membrane pattern of staining in almost all the epithelial cells. Specimens of normal colonic epithelium were double stained sequentially with NA1/34 and CAM 5.2 using conjugates of alkaline phosphatase and peroxidase, respectively. This technique showed colocalisation of these antigens in the same cells.

\section{Skin}

NA1/34 showed Langerhans' cells in cryostat sections of skin. These were uniformly negative with CAM 5.2.

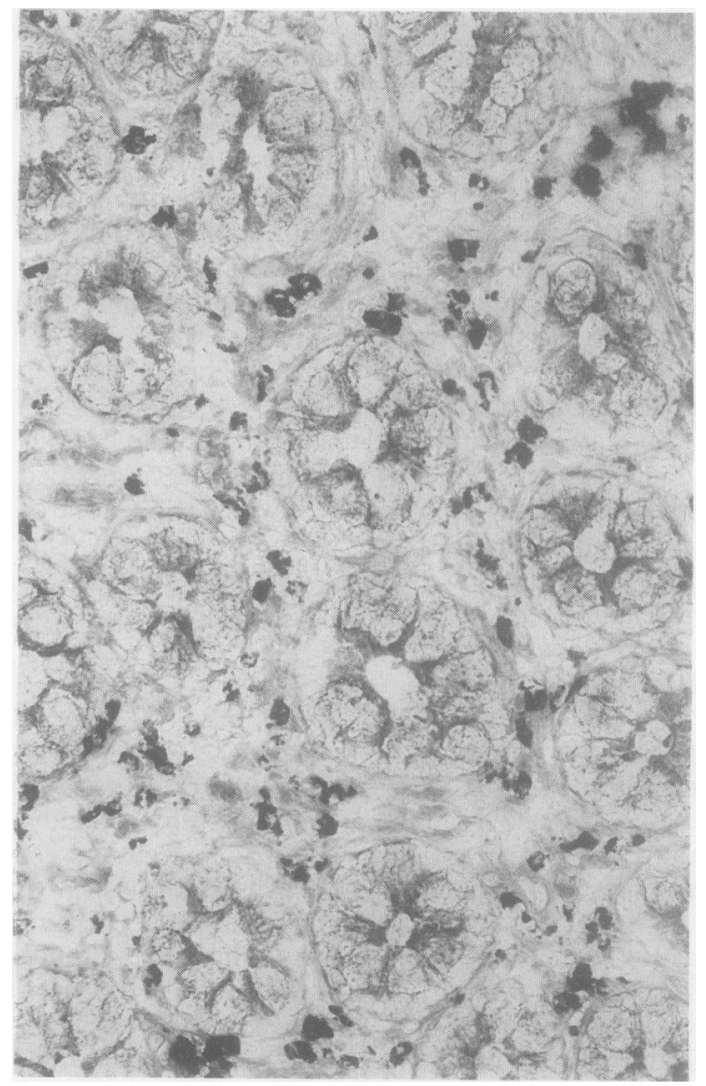

Fig 2 Section of normal colonic epithelium showing membrane staining with anti-CDIa antibody NA1/34. Cells containing endogenous peroxidase are seen in lamina propria. 


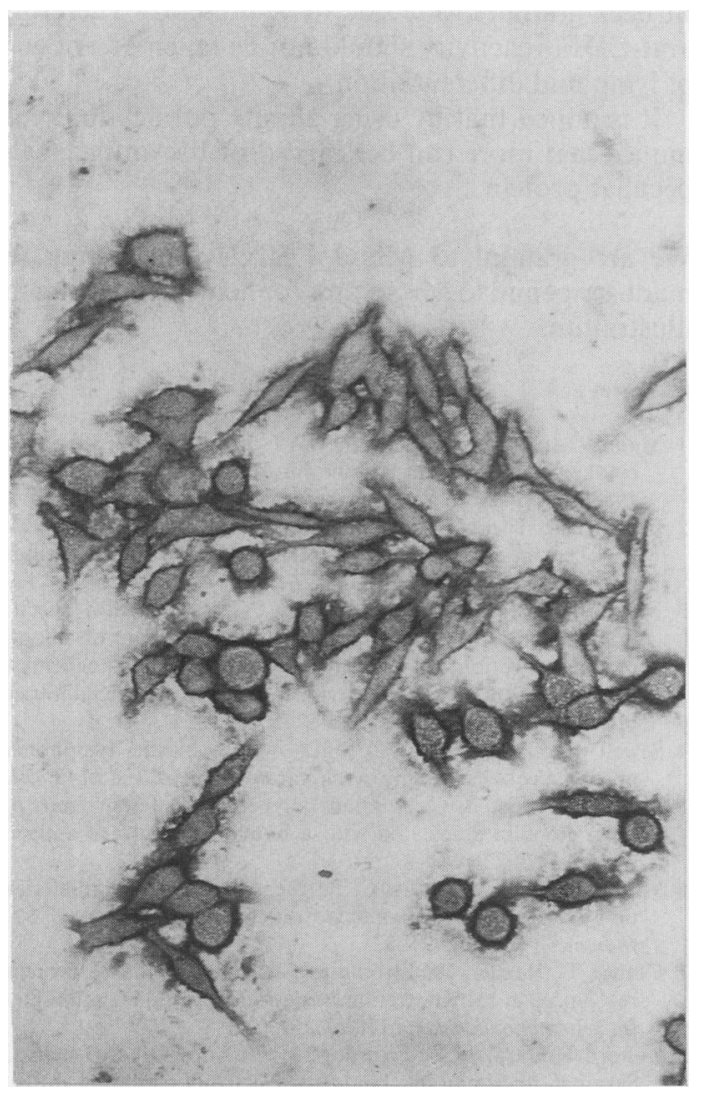

Fig 3 HCT8 (human adenocarcinoma) cells stained with NA1/34. Almost all the cells present show strong membrane staining with this antibody.

\section{IMMUNE BLOTTING}

In HCT 8 cell extracts NA1/34 exhibited a $12 \mathrm{kD}$ band. A $49 \mathrm{kD}$ band was an occasional finding in this material. CAM 5.2 showed a complex pattern of bands between 40 and $50 \mathrm{kD}$ which are the expected molecular weights of the cytokeratins recognised by this antibody. A $12 \mathrm{kD}$ band, identical with that found with NA1/34, was also continually found in this cell line (fig 4).

Studies of lymph node extracts were of limited value with weak and inconsistent staining of bands.

\section{Discussion}

The main finding of this study was the identification by CAM 5.2 and NA1/34 (anti-CD1a) of a common 12 $\mathrm{kD}$ band in Western blot preparations of colonic HCT8 cells. It is very likely that this is the $12 \mathrm{kD} \beta \mathrm{t}$ chain which can be identified in thymus derived cells

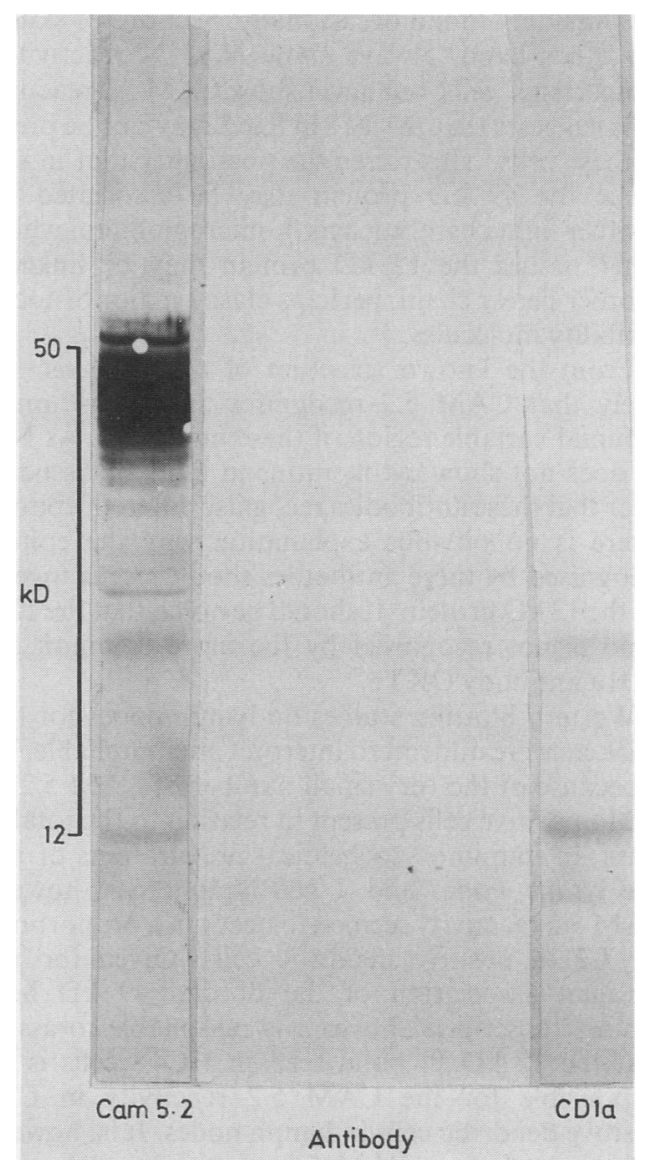

Fig 4 Immunoblot of HCT8 cell extract stained with CAM 5.2 and NA1/34. CAM 5.2 recognises a group of cytokeratin bands and $a$ band at $12 \mathrm{kD}$. NA1/34 also recognises a $12 \mathrm{kD}$ band (arrow). Both antibodies also detect a weak and inconsistent band at intermediate molecular weight. In this specimen no $49 \mathrm{kD}$ band was seen in the NAI/34 stained lane.

by NA1/34. ${ }^{56}$ In these studies the $\beta t$ chain was associated with the $49 \mathrm{kD}$ heavy chain of CDla and dissociated progressively as the temperature was raised. Several other studies have described the weak association of the $49 \mathrm{kD}$ heavy chain with $\beta_{2}$ microglobulin.$^{7-9}$ The near identical molecular weights and shared sequences ${ }^{8}$ of $\beta t$ and $\beta_{2}$-microglobulin, as well as the other similarities of the $49 \mathrm{kD}$ protein with class I major histocompatibility heavy chains, ${ }^{10}$ suggest that these low molecular weight polypeptides may have similar functions.

Interestingly, the $49 \mathrm{kD}$ and $12 \mathrm{kD}$ bands could be detected independently. In some of the preparations of HCT8 cells, in addition to the $12 \mathrm{kD}$ band, a weak band at $49 \mathrm{kD}$ was seen in NAl/34 stained blots but 
this was only found occasionally. Sections of skin, on the other hand, always show NA1/34 reactivity in Langerhans' cells, but never show CAM 5.2 reactivity. This suggests that the $12 \mathrm{kD}$ band may not be present in these cells. This raises the possibility that in some tissue the $49 \mathrm{kD}$ protein may be associated with another light chain, such as $\beta_{2}$-microglobulin, while in other tissues the $12 \mathrm{kD}$ protein may be linked to another heavy chain, perhaps class I major histocompatibility molecules.

From the known structure of cytokeratins ${ }^{12}$ it is likely that CAM 5.2 recognises an epitope on the terminal variable region of these molecules. As NA1/ 34 does not show cytokeratins in blots or tissue it is clear that these antibodies recognise different epitopes. There is no obvious explanation why the epitopes recognised by these antibodies should occur together on the $12 \mathrm{kD}$ protein. It should be noted that the $12 \mathrm{kD}$ band is not recognised by the more common antiCDla antibody OKT6."

Western blotting studies on lymph nodes for these markers were difficult to interpret and unreliable. This is because of the very small number of CAM 5.2 and CDla positive cells present in relation to the total cell mass. In immunocytochemical preparations of reactive lymph nodes and $T$ cell lymphomas, however, CAM 5.2 reactivity seemed to occur in a proportion of the CDla positive dendritic cells. Given the noncovalent association of the $\beta \mathrm{t}$ and $49 \mathrm{kD}$ heavy chains ${ }^{56}$ described above, it is reasonable to assume that the $12 \mathrm{kD} \beta \mathrm{t}$ band seen in HCT8 cells is also responsible for the CAM 5.2 reactivity in CD1a positive dendritic cells in lymph nodes. It is, however, of interest that no CAM 5.2 reactivity is detected in CDla positive Langerhans' cells in skin in view of the apparently close functional and antigenic relation between these cells and the interdigitating reticulin cells of the paracortex.

Although there are several unanswered questions concerning the $12 \mathrm{kD}$ protein described, this observation has several practical implications. Most importantly, the properties of CAM 5.2 make it a useful antibody for detecting single epithelial cells in tissues such as lymph node. In view of the findings of the study great care must be taken in the interpretation of single cells reactive with low molecular weight cytokeratin antibodies. A case of a putative carcinoma which reacted with anti-CD1a antibodies and anti-cytokeratin has been reported, although in this case
Birbeck granules were said to be present. ${ }^{13}$ Therefore, anti-CDla reactivity should not be taken as evidence of lymphoid differentiation.

It is hoped that by using affinity purification techniques that more can be learned of the antigenically peculiar protein.

We are grateful to Mrs $\mathbf{J}$ Fearnley for typing the manuscript and to MrS Toms for help in preparing the illustrations.

\section{References}

1 Makin CA, Bobow LG, Bodmer WT. Monoclonal antibody to cytokeratin for use in routine histopathology. J Clin Pathol 1984;37:975-83.

2 Brown DC, Theaker JM, Banks PM, Gatter KC, Mason DY. Cytokeratin expression in smooth muscle and smooth muscle tumours. Histopathol 1987;11:477-86.

3 Norton AJ, Thomas JA, Isaacson PG. Cytokeratin specific monoclonal antibodies are reactive with tumours of smooth muscle derivation. An immunocytochemical and histochemical study using antibodies to intermediate filament skeletal muscle proteins. Histopathol 1987;11:487-500.

4 Sewell H, Thompson WD. IgD immunoblastic lymphoma/ myeloma cells expressing cytokeratins. J Pathol 1986;148:82A.

5 Ziegler A, Milstein C. A small polypeptide different from $\beta_{2-}$ microglobulin associated with a human cell surface antigen. Nature 1979;279:243-4.

6 Van Agthoven A, Terhorst C. Further biochemical characterisation of the human thymocyte differentiation antigen T6. $J$ Immunol 1982;128:426-32.

7 Cotner T, Hemler M, Strominger JL. Human T-cell proteins recognised by rabbit heteroantisera and monoclonal antibodies. Int J Immunopharmacol 1981;3:255-68.

8 Kefford RF, Calabi F, Fearnley IM, Burrone OR, Milstein C. Serum $\boldsymbol{\beta}_{2}$-microglobulin binds to a T-cell differentiation antigen and increases its expression. Nature 1984;308:641-2.

9 Bernaben C, Van de Rijn M, Lerch PG, Terhorst C. $\beta_{2}$ microglobulin from serum associated with MHC class I antigens on the surface of cultivated cells. Nature 1984;308: 642-3.

10 Terhorst C, Van Agthoven A, Le Clair K, Snow P, Reinberz E, Schlossman S. Biochemical studies of the human thymocyte in cell surface antigens T6, T9 and T10. Cell 1981;23:771-80.

11 Amiot M, Bernard A, Raynal B, Knapp W, Deschildre C, Bounsell L. Heterogeneity of the first cluster of differentiation: characterisation and epitopic mapping of three CD1 molecules on normal human thymus cells. $J$ Immunol 1986;126:1752-8.

12 Steinert PM, Parry DAD. Intermediate filaments: conformity and diversity of expression and structure. Ann Rev Cell Biol 1985;1:41-65.

13 West K, Chapman C, Campbell H, Lauder I. A tumour reactive with CD1 and cytokeratin antibodies. J Pathol 1987;151:41 A.

Requests for reprints to: Dr A S Jack, Department of Pathology, University of Leeds, Leeds, LS2 9JT, England. 